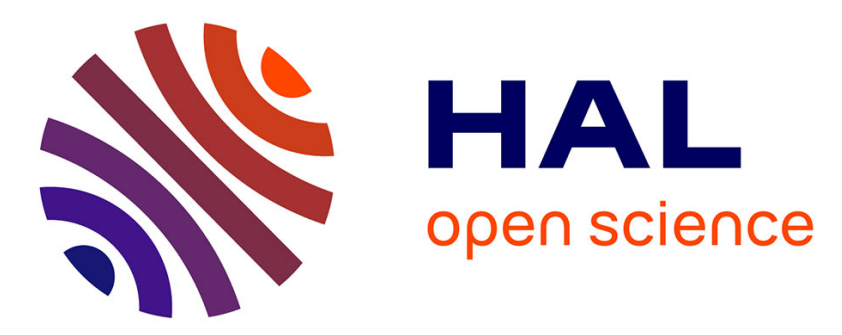

\title{
Metabolic activity of intertidal Fucus spp. communities: evidence for high aerial carbon fluxes displaying seasonal variability
}

François Bordeyne, Aline Migné, Dominique Davoult

\section{- To cite this version:}

François Bordeyne, Aline Migné, Dominique Davoult. Metabolic activity of intertidal Fucus spp. communities: evidence for high aerial carbon fluxes displaying seasonal variability. Marine Biology, 2015, 162 (10), pp.2119-2129. 10.1007/s00227-015-2741-6 . hal-01212165

\section{HAL Id: hal-01212165 \\ https: / hal.sorbonne-universite.fr/hal-01212165}

Submitted on 6 Oct 2015

HAL is a multi-disciplinary open access archive for the deposit and dissemination of scientific research documents, whether they are published or not. The documents may come from teaching and research institutions in France or abroad, or from public or private research centers.
L'archive ouverte pluridisciplinaire HAL, est destinée au dépôt et à la diffusion de documents scientifiques de niveau recherche, publiés ou non, émanant des établissements d'enseignement et de recherche français ou étrangers, des laboratoires publics ou privés. 
1 TITLE: Metabolic activity of intertidal Fucus spp. communities: evidence for high aerial

2 carbon fluxes displaying seasonal variability.

3

4 Authors:

$5 \quad$ François Bordeyne ${ }^{1,2}$, Aline Migné ${ }^{1,2}$, Dominique Davoult ${ }^{1,2}$

6

7 Affiliations and addresses:

$8{ }^{1}$ Sorbonne Universités, UPMC Univ. Paris 6, UMR 7144, Station Biologique de Roscoff,

9 Place Georges Teissier, 29688 Roscoff Cedex, France

$10{ }^{2}$ CNRS, UMR 7144, Station Biologique de Roscoff, Place Georges Teissier, 29688 Roscoff

11 Cedex, France

12

13 Corresponding author:

14 François Bordeyne

15 Email: francois.bordeyne@sb-roscoff.fr

16 Phone: 0033298292333

17 Fax number: 0033298292324

19 ABSTRACT

20 Semi-sheltered rocky shores are characterized by a typical succession of Phaeophycean-

21 dominated communities where canopy-forming algae are assumed to be very productive.

22 However, metabolic activity of whole communities, integrating the main interactions that

23 occur in these assemblages, still needs to be investigated more deeply, especially when

24 communities are emerged. Thus, the metabolism of the mid-intertidal Fucus vesiculosus and

25 Fucus serratus communities was surveyed once a month throughout a year in the Bay of 
Morlaix (France). In situ measurements of primary production and respiration were carried out at the onset of emersion periods, using benthic chambers coupled to $\mathrm{CO}_{2}$-infrared gas analysers. Benthic measurements were performed successively on whole communities and after canopy removal, to assess the contribution of the canopies to the communities' carbon fluxes. Concurrently, nitrogen and organic carbon contents of the two Fucus species were evaluated monthly. Both communities exhibited high metabolic activity year-round (community gross primary production: $400-1000 \mathrm{mgC} \mathrm{m}^{-2} \mathrm{~h}^{-1}$; community respiration: 100$500 \mathrm{mgC} \mathrm{m}^{-2} \mathrm{~h}^{-1}$ ), with canopies accounting for $77-97 \%$ of the global $\mathrm{CO}_{2}$ fluxes. However, this relative canopies' contribution to global $\mathrm{CO}_{2}$ fluxes did not follow seasonal fluctuations, whereas both metabolic activities and nitrogen and carbon contents did, confirming the importance of light and temperature in the regulation of metabolic processes. A nutrient limitation was also suggested to occur in summer, when seawater was nutrient-depleted. Finally, the Fucus vesiculosus community, located upper on the shore, exhibited lower photosynthetic activity than the Fucus serratus community, being consistent with the vertical zonation rules of intertidal habitats.

\section{INTRODUCTION}

Communities dominated by canopy-forming Phaeophyceae are particularly widespread along intertidal rocky shores of temperate regions. Such communities are usually considered to be very productive, although their metabolism has rarely been studied at the community scale (Golléty et al. 2008; Tait and Schiel 2010). Yet, these communities are constituted of numerous species (Rindi and Guiry 2004; Kersen et al. 2011; Migné et al. 2015b), giving rise to many interactions. For instance, numerous trophic relationships occur in these systems (Golléty et al. 2010; Duarte et al. 2015), as well as competition for light and space (Underwood 2000). Such interactions could lead to large variability in the metabolism of 
primary producers. They must for instance synthesize defence molecules against grazers, epibionts and/or biofilms (Brock et al. 2007; Wahl 2009) or are subjected to a reduced light due to epibionts, leading to a reduction of photosynthetic activity (Sand-Jensen 1977; Oswald et al. 1984). On the contrary, Tait and Schiel (2011) demonstrated that the structural differences of primary producers, but also their location in the community assemblage could lead to an enhancement of the global primary production. Therefore, all these interactions play a fundamental role and need to be accounted for when investigating community metabolism, as highlighted by Migné et al. (2015a).

These communities also experiment large changes in abiotic conditions at various temporal scales. The most drastic change occurs at the tidal scale, due to the alternation of immersion and emersion periods. Although usually thought as stressful for intertidal organisms, emersion periods can, however, be a very useful time for algae to do photosynthesis (Golléty et al. 2008), with some of them exhibiting the major part of their production when emersed (Quadir et al. 1979). Thus, investigations of intertidal communities' metabolic activity should not neglect the low tide periods.

The study of Golléty et al. (2008) is to our knowledge the first one dealing with in situ metabolic activity of Phaeophycean dominated communities under emersed conditions. This pioneer study showed that primary production and respiration rates of the sheltered midintertidal Ascophyllym nodosum community followed a seasonal trend related to changes in light availability and temperature, and that the canopy and its epibionts were responsible for the huge majority of community' carbon fluxes.

Following the principles of the intertidal zonation of canopy-forming species and the general relationship between diversity of marine species and tidal level (Raffaelli and Hawkins 1999; Molina-Montenegro et al. 2005), it could be expected that the tidal level at which the 
communities are established is of paramount importance in controlling the magnitude and the seasonal variability of their metabolism, as well as the contribution (and its seasonal variability) of the canopy to the total metabolism. Furthermore, the hydrodynamism to which the communities are exposed and specific environmental conditions (e.g. nutrient depletion), could as well have an influence on these parameters. In the current context of harvesting of Phaeophyceae along European West coasts (Jacob et al. 2012), it appears crucial to better understand the year-round dynamic of the communities they form, but also the way these canopy-forming species contribute to this dynamic.

In addition, some essential information on algae-environment interactions could be obtained considering the elemental composition of canopy-forming Phaeophyceae, which was shown to reflect both assimilation and use of nutrients and organic compounds by the algae (Chapman and Craigie 1977; 1978). This appears to be particularly attractive in intertidal systems since algae have to rely on their own nitrogen reserves when emerged (Pedersen and Borum 1997).

Mid- and low-mid intertidal communities dominated respectively by canopy-forming algae Fucus vesiculosus Linnaeus and Fucus serratus Linnaeus are particularly widespread along European coasts (Jueterbock et al. 2013). This study focused on the metabolic activity of these two adjacent communities, using in situ carbon fluxes measurements performed at the onset of emersion periods, under saturating irradiance. We hypothesized that (1) while following temporal variations, their gross primary production and respiration remained substantial all over the year, that (2) canopies consistently acted as the major contributor of total carbon fluxes in the communities, with this contribution following seasonal pattern, and that (3) the nitrogen and organic carbon contents of the canopies also varied with seasons and environmental conditions. Finally, we also hypothesized that (4) the lower shore community 
101 exhibited a higher metabolic competitiveness than the upper shore community, in accordance

102 with the principles of vertical zonation of canopy species.

103

MATERIALS \& METHODS

105

Study site

106 This study was performed on $F$. vesiculosus and $F$. serratus communities established on an

107 intertidal semi-sheltered boulder reef located in front of the Station Biologique de Roscoff

108 (Brittany, France) $\left(48^{\circ} 43.743^{\prime}\right.$ N, $\left.3^{\circ} 59.407^{\prime} \mathrm{W}\right)$, in the southwest part of the English Channel.

109 On this reef, these communities form dense and multi-layer assemblages which frequently

110 cover $100 \%$ of the substratum, making it an ideal place to study their metabolism. This shore

111 is subjected to semi-diurnal tidal cycle with maximal range of about $9 \mathrm{~m}$. It presents a typical

112 vertical distribution of communities dominated by canopy-forming Phaeophyceae, where $F$.

113 vesiculosus community is characteristic of the mid-intertidal (3.0 to $4.0 \mathrm{~m}$ above chart datum,

114 corresponding to an annual emerged time of 20-35\%) while F. serratus community is

115 characteristic of the low mid-intertidal (2.5 to $3.0 \mathrm{~m}$ above chart datum, corresponding to an 116 annual emerged time of $15-20 \%)$.

\section{Environmental conditions}

119 This site, located in the temperate part of Northern hemisphere, displays a seasonal day:night

120 cycle varying from 9:15 in late December to 16:8 in late June. It is also subjected to seasonal

121 variations of irradiance and temperature. The weather station of Brest-Guipavas (located at

122 approx. $40 \mathrm{~km}$ of our study site) provided monthly maximal instantaneous irradiance (Maxirr,

123 in $\left.\mathrm{W} \mathrm{m}^{-2}\right)$ and monthly mean air temperature $\left(\mathrm{T}_{\text {air }}\right.$, in $\left.{ }^{\circ} \mathrm{C}\right)$ datasets (October 2012 - December

124 2013). The SOMLIT network (sampling site: Estacade, Roscoff, located at approx. $600 \mathrm{~m}$ of

125 our study site) provided monthly mean seawater temperature $\left(\mathrm{T}_{\text {seawater }}\right.$, in $\left.{ }^{\circ} \mathrm{C}\right)$ and monthly 

(October 2012 - December 2013).

128

means seawater nutrient concentrations $\left(\mathrm{NH}_{4}{ }^{+}, \mathrm{NO}_{3}{ }^{2-}, \mathrm{NO}_{2}{ }^{-}\right.$and $\mathrm{PO}_{4}{ }^{3-}$, in $\left.\mu \mathrm{mol} \mathrm{L}{ }^{-1}\right)$ datasets

\section{Benthic metabolism measurements and sampling}

Measurements of benthic metabolism of $F$. vesiculosus and $F$. serratus communities were performed once a month from October 2012 to December 2013, with the exception of

December 2012. They were always done at the onset of emersion of a spring tide (around midday) to avoid a desiccation effect on metabolic rates. At each occasion, three intra-site replicates ( 2 to $5 \mathrm{~m}$ distance between each) of a $0.09 \mathrm{~m}^{2}$ rock area were haphazardly selected for both communities (only two replicates in November 2013 for F. serratus community). A replicate included one to several Fucus thalli (> $25 \mathrm{~cm}$ long) with the associated community, which was essentially made-up of Fucus epibionts (i.e. algae and sessile invertebrates directly attached to the Fucus, see Wahl 2009) and biofilms, as well as sub-canopy and encrusting macroalgae, rocky and sedimentary microphytobenthos and invertebrates, including the mobile ones on Fucus fronds. Each area was then enclosed in a custom-built incubation chamber $(17.7 \mathrm{~L})$ made of clear Plexiglas, connected to an infrared $\mathrm{CO}_{2}$ gas analyzer (LiCor Li-820) in closed air circuit. Air motion of $1 \mathrm{~L} \mathrm{~min}^{-1}$ was ensured by a pump in this closed circuit. $\mathrm{CO}_{2}$ fluxes measurements were performed at the rock-air interface, as described by Migné et al. (2002), at ambient light and in darkness by covering up the chambers. These measurements allowed estimating the total community net primary production $\left(\mathrm{NPP}_{\mathrm{t}}\right)$ and the total community respiration $\left(\mathrm{CR}_{\mathrm{t}}\right)$, respectively, assuming that $\mathrm{CO}_{2}$ fluxes measured in darkness after abrupt transition from ambient light reflected the respiration activity of the communities (del Giorgio and Williams 2005). Incubations were sufficiently short (i.e. 5 - 10 min) to avoid feedback of temperature and gas concentration changes on metabolic rates.

Total community gross primary production $\left(\mathrm{GPP}_{\mathrm{t}}\right)$ was calculated as $\mathrm{GPP}_{\mathrm{t}}=\mathrm{NPP}_{\mathrm{t}}+\mathrm{CR}_{\mathrm{t}} \cdot \mathrm{CO}_{2}$ 
151 fluxes were calculated from recorded data using the slope of $\mathrm{CO}_{2}$ concentration $\left(\mu\right.$ mol $\mathrm{CO}_{2}$

152 mol $\left._{\text {air }}{ }^{-1}\right)$ against time $(\mathrm{min})$. Therefore, $\mathrm{GPP}_{\mathrm{t}}$ and $\mathrm{CR}_{\mathrm{t}}$ were expressed in carbon unit $\left(\mathrm{mgC} \mathrm{m}^{-2}\right.$

$153 \mathrm{~h}^{-1}$ ) assuming a molar volume of $22.4 \mathrm{~L} \mathrm{~mol}^{-1}$ at standard temperature and pressure and a

154 molar mass of $12 \mathrm{gC} \mathrm{mol}_{\mathrm{CO}_{2}}^{-1}$. Finally, the community metabolic balance was calculated each

155 month for both communities as the ratio of $\mathrm{CR}_{\mathrm{t}}$ to $\mathrm{GPP}_{\mathrm{t}}$.

156 After performing this first set of light and dark incubations, Fucus thallus and the associated

157 epibionts and biofilms were removed from the incubation chambers, while mobile fauna being

158 on the fronds was left inside of the chambers with the remaining organisms (including algae

159 and invertebrates). A second set of light and dark incubations was performed on this residual

160 community, in order to estimate residual community net primary production $\left(\mathrm{NPP}_{\mathrm{r}}\right)$ and

161 residual community respiration $\left(\mathrm{CR}_{\mathrm{r}}\right)$. Residual community gross primary production $\left(\mathrm{GPP}_{\mathrm{r}}\right)$

162 was calculated following the formula used previously $\left(\mathrm{GPP}_{\mathrm{r}}=\mathrm{NPP}_{\mathrm{r}}+\mathrm{CR}_{\mathrm{r}}\right)$. These

163 measurements allowed to determine the contribution of the canopy to the carbon fluxes of the

164 community $\left(\mathrm{GPP}_{\mathrm{can}}=\mathrm{GPP}_{\mathrm{t}}-\mathrm{GPP}_{\mathrm{r}} ; \mathrm{CR}_{\mathrm{can}}=\mathrm{CR}_{\mathrm{t}}-\mathrm{CR}_{\mathrm{r}}\right)$.

165 Removed canopies were brought back to the laboratory to measure their dry masses after

166 drying for $48 \mathrm{~h}$ at $60{ }^{\circ} \mathrm{C}$. Dry masses were used to calculate the respiration rate of canopies

$167\left(\mathrm{R}_{\mathrm{can}} / \mathrm{DM}_{\mathrm{can}}\right)$ and their productivity $\left(\mathrm{GPP}_{\mathrm{can}} / \mathrm{DM}_{\mathrm{can}}\right)$ expressed in $\mathrm{mgC} \mathrm{g}_{\mathrm{DM}}{ }^{-1} \mathrm{~h}^{-1}$.

168

169 Incident photosynthetically available radiation $(400-700 \mathrm{~nm})$ was recorded (LiCor

170 QuantumSA-190, $\mu$ mol photons $\mathrm{m}^{-2} \mathrm{~s}^{-1}$ ) close to the incubation chambers. Mean values during

171 measurements at ambient light varied from $465 \mu \mathrm{mol}$ photons $\mathrm{m}^{-2} \mathrm{~s}^{-1}$ in December 2013 to

$1722094 \mu \mathrm{mol}$ photons $\mathrm{m}^{-2} \mathrm{~s}^{-1}$ in June 2013. Measurements were thus assumed to be done under

173 saturating irradiance, based on the average value of $291 \mu \mathrm{mol}$ photons $\mathrm{m}^{-2} \mathrm{~s}^{-1}$ given for the

174 onset of light saturation of coastal macroalgal communities (Middelboe et al. 2006).

175 
177 Just before drying the removed canopies as mentioned previously, samples $(\approx 1 \mathrm{~g}$ of fresh weight) were taken from Fucus fronds of each replicate, to assess their $\mathrm{C}$ and $\mathrm{N}$ contents.

179 These sampling were done from January to December 2013. Samples were rinsed with

180 distilled water before being dried $\left(60^{\circ} \mathrm{C}, 48 \mathrm{~h}\right)$ and ground to a fine powder using a mortar and 181 pestle. C and N mass percentages were determined at the Station Biologique de Roscoff using

182 a Flash EA 1112 CHN analyzer (ThermoFinningan) calibrated against nicotinamide and 183 acetanilide reference materials.

\section{Statistical analysis}

186 Seasonal patterns of $\mathrm{GPP}_{\mathrm{t}}, \mathrm{CR}_{\mathrm{t}}, \mathrm{CR}_{\mathrm{t}} / \mathrm{GPP}_{\mathrm{t}}, \mathrm{GPP}_{\mathrm{can}} / \mathrm{DM}_{\mathrm{can}}, \mathrm{R}_{\mathrm{can}} / \mathrm{DM}_{\mathrm{can}}, \mathrm{C}$ and $\mathrm{N}$ contents were

187 highlighted by fitting a sinusoidal curve to the monthly mean values:

$$
y=a+b \sin \left(\frac{2 \pi}{365} x+c\right)
$$

where $\mathrm{y}$ is the predicted value of the considered parameter, and $\mathrm{x}$ the time in days. $F$-test was used to test the fit, using R software, version 3.1.2 (R Core Team, 2014).

191 Comparisons of the two communities (community metabolism, canopy metabolism and C and

192 N contents) were done using Wilcoxon signed rank test on the mean values for each month,

193 performed with the R software, version 3.1.2 (R Core Team, 2014).

194 Correlations between monthly maximal instantaneous irradiance and PAR recorded during

195 light incubations, and between $\mathrm{N}$ contents and seawater $\mathrm{N}$-nutrients pool, were tested with

196 Pearson coefficient using the R software, version 3.1.2 (R Core Team, 2014).

197 For both communities, the relationship between $\mathrm{GPP}_{t}$ or $\mathrm{CR}_{t}$ and environmental variables was 198 analysed by linear multiple regression (Best procedure and AIC selection criteria) with p-

199 values obtained by permutation, using PRIMER software, version 6.1.12 associated with 200 PERMANOVA+ for PRIMER, version 1.0.2. Predictor variables of $\mathrm{GPP}_{\mathrm{t}}$ consisted of 
monthly maximal instantaneous irradiance, monthly means of air and seawater temperature

and of nutrients seawater concentrations $\left(\mathrm{NO}_{3}{ }^{-}, \mathrm{NO}_{2}{ }^{-}, \mathrm{NH}_{4}{ }^{+}\right.$and $\left.\mathrm{PO}_{4}{ }^{2-}\right)$, and canopy dry mass. Predictor variables of $\mathrm{CR}_{\mathrm{t}}$ consisted of monthly means of air and seawater temperature, and canopy dry mass.

\section{RESULTS}

\section{Environmental conditions}

Monthly maximal instantaneous irradiance followed seasonal trend, with values ranging from $311 \mathrm{~W} \mathrm{~m}^{-2}$ in December 2012 to $1000 \mathrm{~W} \mathrm{~m}^{-2}$ in May 2013 (Fig 1). Our records of incident photosynthetically available radiation during light incubations (data not shown) were

211 significantly correlated with these values $(\mathrm{r}=0.885, p<0.001$ for the $F$. vesiculosus 212 community and $\mathrm{r}=0.784, p<0.001$ for the $F$. serratus community). Monthly mean air and seawater temperatures also followed seasonal trends, with values ranging respectively from $5.8{ }^{\circ} \mathrm{C}$ in February 2013 to $18.2{ }^{\circ} \mathrm{C}$ in July 2013 and from $9.3{ }^{\circ} \mathrm{C}$ in March 2013 to $16.5^{\circ} \mathrm{C}$ in August 2013 (Fig 1). Nitrates $\left(\mathrm{NO}_{3}^{-}\right)$dominated the seawater $\mathrm{N}$-nutrient pool throughout the 216 year, with concentration ranging from $0.19 \mu \mathrm{mol} \mathrm{L}^{-1}$ at the end of July 2013 to $12.45 \mu \mathrm{mol} \mathrm{L}-1$ 217 at the beginning of February 2013 (Fig 2a). Ammonium $\left(\mathrm{NH}_{4}{ }^{+}\right)$, nitrites $\left(\mathrm{NO}_{2}{ }^{-}\right)$and 218 phosphates $\left(\mathrm{PO}_{4}{ }^{2-}\right)$ seawater concentrations also fluctuated throughout the year, but remained 219 lower than $0.75 \mu \mathrm{mol} \mathrm{L}^{-1}$ (Fig 2b).

\section{Benthic metabolism}

222 Fucus vesiculosus community exhibited a gross primary production $\left(\mathrm{GPP}_{\mathrm{t}}\right.$, mean $\left.\pm \mathrm{SE}\right)$

223 ranging from $341.6 \pm 41.0 \mathrm{mgC} \mathrm{m}^{-2} \mathrm{~h}^{-1}$ in March 2013 to $962.9 \pm 195.4 \mathrm{mgC} \mathrm{m}^{-2} \mathrm{~h}^{-1}$ in June 2242013 and respiration $\left(\mathrm{CR}_{\mathrm{t}}\right.$, mean $\pm \mathrm{SE}$ ) ranging from $102.8 \pm 27.1 \mathrm{mgC} \mathrm{m}^{-2} \mathrm{~h}^{-1}$ in February 2252013 to $562.7 \pm 117.1 \mathrm{mgC} \mathrm{m}^{-2} \mathrm{~h}^{-1}$ in August 2013. GPP $_{\mathrm{t}}$ of the Fucus serratus community 
ranged from $440.0 \pm 80.6 \mathrm{mgC} \mathrm{m}^{-2} \mathrm{~h}^{-1}$ in January 2013 to $1104.4 \pm 101.9 \mathrm{mgC} \mathrm{m}^{-2} \mathrm{~h}^{-1}$ in August 2013 and $\mathrm{CR}_{\mathrm{t}}$ ranged from $74.3 \pm 7.9 \mathrm{mgC} \mathrm{m}^{-2} \mathrm{~h}^{-1}$ in January 2013 to $475.9 \pm 65.8$ $\mathrm{mgC} \mathrm{m}^{-2} \mathrm{~h}^{-1}$ in August 2013 (Fig 3). Both $\mathrm{GPP}_{\mathrm{t}}$ and $\mathrm{CR}_{\mathrm{t}}$ of $F$. vesiculosus and F. serratus communities followed a seasonal pattern significantly fitted by sinusoidal curves (Table 1), with minimal values occurring during winter and maximal values occurring during summer, even though a metabolic depression was observed in July. While they followed the same seasonal fluctuations, the $F$. vesiculosus community exhibited significantly lower $\mathrm{GPP}_{\mathrm{t}}$ than $F$. serratus community ( $20 \%$ lower in average) but significantly higher $\mathrm{CR}_{\mathrm{t}}(25 \%$ higher in average) (Table 2). The metabolic balance (i.e. $\mathrm{CR}_{\mathrm{t}} / \mathrm{GPP}_{\mathrm{t}}$ ) was always lower than 1 during our measurements under saturating light conditions. It followed a significant seasonal pattern too (Table 1) with minimal values in winter and maximal values during late summer and early fall (from 0.23 to 0.73 for $F$. vesiculosus community and from 0.16 to 0.45 for $F$. serratus community) (Fig 4). The metabolic balance was significantly higher for the F. vesiculosus community (Table 2), in agreement with the observed differences for both $\mathrm{GPP}_{\mathrm{t}}$ and $\mathrm{CR}_{\mathrm{t}}$ of these communities.

The variability of $\mathrm{GPP}_{\mathrm{t}}$ was best explained by $\mathrm{NO}_{3}{ }^{-}$seawater concentration and $\mathrm{DM}_{\text {can }}$ taken together for the F. vesiculosus community whereas it was best explained by $\mathrm{Max}_{\text {irr }}, \mathrm{T}_{\text {air }}$ and all seawater nutrient concentrations for the F. serratus community (Table 3). The variability of

$\mathrm{CR}_{\mathrm{t}}$ was best explained by the three predictor variables taken together $\left(\mathrm{T}_{\text {air }}, \mathrm{T}_{\text {seawater }}\right.$ and $\mathrm{DM}_{\mathrm{can}}$ ) for the $F$. vesiculosus community whereas it was best explained by $\mathrm{T}_{\text {air }}$ alone for the $F$. serratus community (Table 3 ).

The metabolism of these two communities was consistently dominated by the canopies (i.e. the dominant species and their epibionts) since they accounted for the huge majority of the global $\mathrm{CO}_{2}$ fluxes (77-97\% of $\mathrm{CR}_{\mathrm{t}}$ and $83-95 \%$ of $\mathrm{GPP}_{\mathrm{t}}$ ). Nevertheless, no seasonal pattern 
was observed for the relative contribution of canopies, neither for respiration nor for primary production (F-test, $p>0.05)$. The productivity $\left(\mathrm{GPP}_{\mathrm{can}} / \mathrm{DM}_{\mathrm{can}}\right.$, mean $\left.\pm \mathrm{SE}\right)$ of $F$. vesiculosus canopy ranged from $0.172 \pm 0.029 \mathrm{mgC}_{\mathrm{DM}^{-1}} \mathrm{~h}^{-1}$ in November 2013 to $0.473 \pm 0.072 \mathrm{mgC}$ $\mathrm{g}_{\mathrm{DM}}{ }^{-1} \mathrm{~h}^{-1}$ in June 2013 and its respiration rate $\left(\mathrm{R}_{\mathrm{can}} / \mathrm{DM}_{\mathrm{can}}\right.$, mean $\left.\pm \mathrm{SE}\right)$ from $0.043 \pm 0.010$ $\operatorname{mgC~} \mathrm{g}_{\mathrm{DM}}^{-1} \mathrm{~h}^{-1}$ February 2013 to $0.217 \pm 0.053 \mathrm{mgC}_{\mathrm{DM}}{ }^{-1} \mathrm{~h}^{-1}$ in June 2013. The productivity

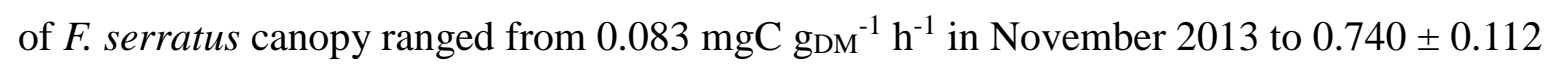
$\mathrm{mgC} \mathrm{g}_{\mathrm{DM}}{ }^{-1} \mathrm{~h}^{-1}$ in April 2013 and its respiration rate from $0.040 \pm 0.008 \mathrm{mgC}_{\mathrm{DM}^{-1}} \mathrm{~h}^{-1}$ in November 2012 to $0.240 \pm 0.027 \mathrm{mgC}_{\mathrm{DM}^{-1}} \mathrm{~h}^{-1}$ in June 2013 (Fig 5). As for whole communities, both productivity and respiration rate of the canopies followed a significant seasonal pattern (Table 1), except for the $F$. vesiculosus productivity (F-test, $p>0.05$ ). Finally, the productivity of $F$. vesiculosus was significantly lower than the one of F. serratus (30\% lower in average). No significant difference was found for respiration rate (Table 2).

\section{Carbon and nitrogen contents}

$\mathrm{C}$ and $\mathrm{N}$ contents measured from Fucus thallus samples exhibited a seasonal pattern significantly fitted by sinusoidal curves (Fig 6, Table 1). For both Fucus species, C content was the lowest in autumn and the highest in summer, ranging from 37.5 to $39.7 \%$ of DM for F. vesiculosus and from 37.8 to $41.7 \%$ of DM for F. serratus. On the contrary, N content was the lowest in summer and the highest in spring, ranging from 0.88 to $2.39 \%$ of DM for $F$. vesiculosus and from 0.99 to $2.16 \%$ of DM for F. serratus (Fig 6). F. serratus held significantly higher $\mathrm{C}$ content but lower $\mathrm{N}$ content than $F$. vesiculosus (Table 2). $\mathrm{N}$ content was significantly correlated with seawater N-nutrient pool, both for F. vesiculosus $(\mathrm{r}=0.694$, $p=0.012)$ and $F$. serratus $(\mathrm{r}=0.665, p=0.018)$.

\section{DISCUSSION}


By measuring in situ metabolism of intertidal Fucus vesiculosus and F. serratus communities under saturating irradiance, this study highlights that, whatever the season, these communities display a substantial metabolic activity at the beginning of emersion periods. Our results of metabolic activity overlapped those previously obtained for Ascophyllum nosodum community (188-846 $\mathrm{mgC} \mathrm{m}^{-2} \mathrm{~h}^{-1}$ for $\mathrm{GPP}_{\mathrm{t}}$ and $122-616 \mathrm{mgC} \mathrm{m}^{-2} \mathrm{~h}^{-1}$ for $\mathrm{CR}_{\mathrm{t}}$, Golléty et al. 281 2008). Consequently, in such latitudes, intertidal Phaeophycean-dominated communities appear to be photosynthetically active and efficient throughout the year, even though measurements were performed under emerged conditions, which are often considered to be very stressful (Wahl et al. 2011, and references therein). This study also confirms that

Phaeophycean-dominated communities are the most productive systems of intertidal habitats. Indeed, $F$. vesiculosus and $F$. serratus communities displayed considerable higher year-round mean $\mathrm{GPP}_{\mathrm{t}}$ (in $\mathrm{mgC} \mathrm{m}^{-2} \mathrm{~h}^{-1}$ ) than those obtained in studies using the same in situ measurement method, i.e. 7 to 9 times higher than a Zostera noltei bed (Ouisse et al. 2010), 15 to 20 times higher than a muddy-sand community (Migné et al. 2004) or 35 to 44 times higher than a sandy beach community (Hubas et al. 2006). All these studies were conducted at the community scale, integrating the interactions between species and their responses to a broad 292 range of local conditions, especially of incident light (Middelboe et al. 2006; Tait and Schiel 2011; Migné et al. 2015a), and accounting for the contribution of biofilms which is known to

294 be highly significant, both for autotrophic and heterotrophic activities (Golléty and Crowe 295 2013).

297 As expected, both $\mathrm{GPP}_{\mathrm{t}}$ and $\mathrm{CR}_{\mathrm{t}}$ exhibited a seasonal pattern, with minima in winter and 298 maxima in summer, in each community. Such seasonal pattern is in agreement with the 299 general idea that light availability and temperature act as the major drivers of community 300 metabolism (Davison 1991; Golléty et al. 2008; Ouisse et al. 2010; Kemp and Testa 2011). 
However, inorganic seawater nutrient concentrations also act as a key factor of metabolic

302 regulation of marine systems. Photosynthesis can be limited by low nutrient concentrations

303 which affect algal growth and lead to changes in the structure and the food webs of the

304 communities (Bosman et al. 1987). In this study, a gross primary production depression was

305 observed in July for both $F$. vesiculosus and F. serratus communities and matched with the

306 lowest records in seawater nutrient concentrations close to the study site, suggesting that a

307 nutrient limitation has occurred during this period. The same depression in primary

308 production was observed in summer for the A. nodosum community (Golléty et al. 2008), also

309 matching with the lowest seawater nutrient concentrations (SOMLIT network data),

310 strengthening this nutrient limitation hypothesis. Furthermore, the multiple correlations

311 analyses showed that the variability of $\mathrm{GPP}_{\mathrm{t}}$ was best explained by incident light, air

312 temperature and seawater nutrient concentrations in F. serratus community, and by $\mathrm{NO}_{3}$

313 concentration and canopy dry mass in F. vesiculosus community. Surprisingly, neither incident

314 light nor temperature appeared in the best model of regressions for $\mathrm{GPP}_{\mathrm{t}}$ of $F$. vesiculosus

315 community. It can be hypothesized that as the F. vesiculosus community is located upper on

316 the shore than the F. serratus community, it has a more restricted access to seawater nutrients,

317 inducing a higher susceptibility to nutrient limitation, and particularly to nitrates, which

318 dominate the nutrient pool.

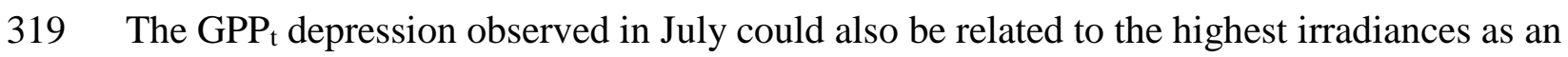

320 excess of light could act as significant stress for photo-autotrophic organisms (e.g. Huppertz

321 et al. 1990; Häder and Figueroa 1997; Bischof et al. 2000). However, Creis et al. (2015) have

322 demonstrated that the exposition of $F$. vesiculosus individuals to UV-B conditions

323 approximately two times more important than the maximal conditions occurring in Brittany

324 only led to a slight reduction in the maximal efficiency of PSII after 1 and 4 weeks of chronic

325 exposure. In addition, as we were working at the community scale, only the upper layer of the 
community (mainly composed of Fucus spp.) was exposed to high light, and could have

327 suffer from it. This layer acted as a protective layer for the other components of the community, which benefited from the attenuation of incident light and could have maintained a high metabolic activity. The canopy biomass appeared to be a good predictor of metabolic variations of the F. vesiculosus community GPP . Binzer and Sand-Jensen (2002)

331 demonstrated that at high density, photosynthetic tissues have the ability to fully use incident

332 light. This would imply an optimal distribution and utilisation of incident light among all 333 photosynthetic tissues in the community. Nevertheless, at very high canopy density,

334 photosynthetic activity could be limited under high light due to uneven distribution of photons 335 (Binzer and Sand-Jensen 2002).

336 During our measurements, F. vesiculosus and F. serratus communities always performed as 337 autotrophic entities, with a $\mathrm{CR}_{t} / \mathrm{GPP}_{\mathrm{t}}$ ratio strictly lower than 1 . Interestingly, this metabolic 338 balance fluctuated according to a seasonal pattern, as did photosynthesis and respiration. Such 339 pattern could be related to the seasonal fluctuations of the biomass of these communities, as 340 the metabolic balance was maximal in summer when maximal biomass accumulation 341 occurred. Indeed, community gross primary production is limited at high canopy density 342 while it respiration rate is linearly related to its density (Binzer and Sand-Jensen 2002).

343 Finally, this seasonal variation implies that metabolic balance has to be used with caution if 344 measured punctually, particularly when dealing with the annual carbon budget of an 345 ecosystem.

347 By removing $F$. vesiculosus and $F$. serratus canopies, we showed that they were responsible 348 for the great majority of $\mathrm{CO}_{2}$ fluxes (77-97\% of $\mathrm{CR}_{\mathrm{t}}$ and $83-95 \%$ of $\left.\mathrm{GPP}_{\mathrm{t}}\right)$. This confirms that 349 the role of canopy-forming macroalgae in the community is not restricted to facilitation for 350 associated species, but is also fundamental in the community metabolism, all over the year. 
No seasonal pattern emerged however, even though diversity and abundance of epibionts and

352 others species, like the opportunistic ones, are known to exhibit a strong seasonal variability (e.g. Rindi and Guiry 2004). Being substantial productive entities, canopy-forming algae can control the community processes they dominate, to constitute one of the major suppliers of organic carbon for coastal food webs (Paine 2002; Golléty et al. 2008). By this way, the 356 global current decline of canopy-forming macroalgae (Airoldi and Beck 2007; Duarte et al.

357 2013) and the predicted shift of European F. vesiculosus and F. serratus communities northward (Jueterbock et al. 2013; 2014) are likely to have dramatic effects on the dynamics

359 of coastal ecosystems (Thompson et al. 2002).

As major metabolic component of their communities, the $F$. vesiculosus and $F$. serratus

362 canopies rationally exhibited high productivity and respiration rate (in $\mathrm{mgC}_{\mathrm{DM}}{ }^{-1} \mathrm{~h}^{-1}$ ). These 363 rates were found to be in the same range as those obtained for other slow-growing

364 Phaeophyceae (e.g. Quadir et al. 1979; Williams and Dethier 2005; Golléty et al. 2008). Yet, 365 some previous studies on Fucus spp. indicated productivity 2 to 10 times higher than our 366 results (Brinkhuis et al. 1976; Maberly and Madsen 1990; Kawamitsu and Boyer 1999) 367 whereas respiration rates were quite similar. These high productivities might be explained by 368 the use of fucoids segments under laboratory conditions, contrasting with our in situ 369 conditions, where the canopies consisted of multi-layer assemblages subjected to strong self370 shading, at least for the basal layers. Furthermore, canopies were considered as a multi371 specific complex, composed of Fucus thalli associated with their epibionts (e.g. Chlorophyta, 372 Rhodophyta, Bryozoa, Tunicates, etc.) and biofilms. These species probably acted as 373 productivity inhibitors due to light attenuation, at least for the heterotrophic ones, as 374 demonstrated by Sand-Jensen (1977) on eelgrass leaves. Considering this, our results 375 appeared to be realistic about what really happened on the field. As for whole communities, a 
seasonal pattern of productivity and respiration rate was observed, except for $F$. vesiculosus productivity, confirming the previous hypothesis about metabolic drivers. The $\mathrm{C}$ contents of both species followed a clear seasonal pattern, as those well described for Laminaria species (e.g. Gagné et al. 1982; Gevaert et al. 2001), with the highest C content in summer, when C assimilation by photosynthesis exceeds $\mathrm{C}$ requirements, leading to a storage of carbohydrates (Gomez and Wiencke 1998; Lehvo et al. 2001) and the lowest in winter when photosynthesis was not sufficient to supply $\mathrm{C}$ requirements, leading to a gradual use of carbohydrate reserves (Hatcher et al. 1977; Lehvo et al. 2001). Any variation in C content due to reproduction investment was detected while both species are known to exhibit seasonal trend in their reproductive strategy (Knight and Parke 1950; Brenchley et al. 1998). Yet, this reproductive process is known to be spread over several months (Knight and Parke 1950), with resources investment rarely exceeding 55\% and fertile individuals found year-round (Brenchley et al. 1998). The $\mathrm{N}$ contents also followed seasonal variations, which are well documented in the literature too (e.g. Asare and Harlin 1983; Carlson 1991; Brenchley et al. 1998; Young et al. 2007). For both species, $\mathrm{N}$ content was highest in winter and lowest in summer, and was significantly correlated with seawater N-nutrient concentrations, as already observed by Young et al. (2007). This is also consistent with the $\mathrm{N}$ turnover rate of approximately 2 to 3 weeks exhibited by $F$. vesiculosus (Viana et al. 2015). High seawater nutrient availability in winter allowed a substantial $\mathrm{N}$ assimilation and storage by Fucus species. Stored $\mathrm{N}$ is gradually used to support an active growth during spring and summer, when N-seawater is depleted. Nutrients limitation of metabolic activity, supposed to occur at community scale, is strengthened by N contents values. Indeed, Pedersen and Borum (1997) have calculated a critical $\mathrm{N}$ tissue content of $1.71 \%$ of DM to support maximum growth rate for $F$. vesiculosus. Lower contents were observed during several months in our F. vesiculosus and F. serratus individuals. Yet, we could expect a seasonal fluctuation of critical $\mathrm{N}$ concentration and/or N- 
401

402

403

404

405

406

407

408

409

410

requirements for these species, which could restrict N-limitation during summer months, when both $\mathrm{N}$ tissue and seawater nutrient concentrations were the lowest.

This study allowed the comparison of the metabolism, at the beginning of the emersion period and under saturating irradiance, of two adjacent communities along the vertical zonation. The upper community exhibited the lowest $\mathrm{GPP}_{\mathrm{t}}$ and the highest $\mathrm{CR}_{\mathrm{t}}$, and as a consequence, the highest metabolic balance. The canopy productivity was also lower for F. vesiculosus than for F. serratus. This is consistent with the C content values, significantly lower in $F$. vesiculosus than in F. serratus. Differences in C content were particularly pronounced during summer and fall, when a higher net primary production for F. serratus was observed. Moebus et al. (1974) have evidenced that lower $\mathrm{C}$ contents in upper species could be a consequence of a higher organic $\mathrm{C}$ release during low tide in response to a higher desiccation degree. Finally, $F$. serratus appeared to be more competitive than $F$. vesiculosus in a metabolic point of view, in agreement with the vertical zonation rules (Raffaelli and Hawkins 1999). The latter species has probably achieved more efficient, but costly, protecting mechanisms to deal with abiotic stresses, such as temperature or desiccation, to the detriment of its competitiveness. This could cause high differences in the annual carbon balance of adjacent communities and needs to be investigated in details further.

\section{Conclusion and perspectives}

This study showed that the two widespread Fucus vesiculosus and F. serratus communities exhibited high rates of both gross primary production and respiration all over a year, confirming their importance in the intertidal area. Nevertheless, as our measurements were achieved at the beginning of emersion for each community, further investigations need to be performed, using complementary methods, to survey the metabolism of these intertidal 
communities during tidal and daily cycles. This is essential to assess accurately the annual carbon balance of such Phaeophycean-dominated systems to bring some insights about their functional ecology, but also to carry on such measurements with the prospect to get fundamental information about ecosystem functioning modifications due to the large and complex changes that occur on the biosphere (Staehr et al. 2012).

\section{AKNOWLEDGMENTS}

The authors thank all the EFEB team members and the students for their help on field experiments. We also thank Cédric Leroux for performing the carbon and nitrogen spectral analyses, and the SOMLIT network for performing seawater temperature and nutrient concentrations measurements. Three anonymous reviewers are thanked for constructive comments. This work benefited from the support of the French Government run by the National Research Agency and with regards to the investment expenditure programme IDEALG ANR-10-BTBR and was partly funded by the Brittany region.

\section{BIBLIOGRAPHY}

Airoldi L, Beck MW (2007) Loss, status and trends for coastal marine habitats of Europe. In: Gibson RN, Atkinson RJA, Gordon JDM (eds) Oceanography and Marine Biology, Vol 45. Taylor \& Francis Group, Boca Raton, pp 345-405

Asare SO, Harlin MM (1983) Seasonal fluctuations in tissue nitrogen for five species of perenniel macroalgae in Rhode Island Sound. J Phycol 19:254-257. doi: 10.1111/j.0022-3646.1983.00254.x

Binzer T, Sand-Jensen K (2002) Importance of structure and density of macroalgae communities (Fucus serratus) for photosynthetic production and light utilisation. Mar Ecol Prog Ser 235:53-62. doi: 10.3354/meps235053 
Bischof K, Hanelt D, Wiencke C (2000) Effects of ultraviolet radiation on photosynthesis and related enzyme reactions of marine macroalgae. Planta 211:555-562. doi: $10.1007 / \mathrm{s} 004250000313$

Bosman AL, Hockey PAR, Siegfried WR (1987) The influence of coastal upwelling on the functional structure of rocky intertidal communities. Oecologia 72:226-232. doi: 10.1007/BF00379273

Brenchley J, Raven J, Johnston A (1998) Carbon and nitrogen allocation patterns in two intertidal fucoids: Fucus serratus and Himanthalia elongata (Phaeophyta). Eur J Phycol 33:307-313. doi: 10.1080/09670269810001736803

Brinkhuis BH, Tempel NR, Jones RF (1976) Photosynthesis and respiration of exposed saltmarsh fucoids. Mar Biol 34:349-359. doi: 10.1007/BF00398128

Brock E, Nylund GM, Pavia H (2007) Chemical inhibition of barnacle larval settlement by the brown alga Fucus vesiculosus. Mar Ecol Prog Ser 337:165-174. doi: $10.3354 /$ meps337165

Carlson L (1991) Seasonal variation in growth, reproduction and nitrogen content of Fucus vesiculosus L. in the Öresund, Southern Sweden. Bot Mar 34:447-453. doi: 10.1515/botm.1991.34.5.447

Chapman ARO, Craigie JS (1977) Seasonal growth in Laminaria longicruris: Relations with dissolved inorganic nutrients and internal reserves of nitrogen. Mar Biol 40:197-205. doi: 10.1007/BF00390875

Chapman ARO, Craigie JS (1978) Seasonal growth in Laminaria longicuris: Relations with reserve carbohydrate storage and production. Mar Biol 46:209-213. doi: 10.1007/BF00390682

Creis E, Delage L, Charton S, Charton S, Goulitquer S, Leblanc C, Potin P, Ar Gall E (2015) Constitutive or inducible protective mechanisms against UV-B radiation in the brown 
alga Fucus vesiculosus? A study of gene expression and phlorotannin content responses. PLOS ONE 10:e0128003. doi: 10.1371/journal.pone.0128003

Davison IR (1991) Environmental effects on algal photosynthesis: Temperature. J Phycol 27:2-8. doi: 10.1111/j.0022-3646.1991.00002.x

del Giorgio PA, Williams PJ le B (2005) Respiration in aquatic ecosystems. Oxford Univ. Press, Oxford

Duarte L, Rossi F, Docal C, Viejo R (2015) Effects of alga Fucus serratus decline on benthic assemblages and trophic linkages at its retreating southern range edge. Mar Ecol Prog Ser 527:87-103. doi: 10.3354/meps 11248

Duarte L, Viejo RM, Martínez B, deCastro M, Gómez-Gesteira M, Gallardo T (2013) Recent and historical range shifts of two canopy-forming seaweeds in North Spain and the link with trends in sea surface temperature. Acta Oecologica 51:1-10. doi: 10.1016/j.actao.2013.05.002

Elser JJ, Bracken MES, Cleland EE, Bracken MES, Cleland EE, Gruner DS, Harpole WS, Hillebrand H, Ngai JT, Saebloom EW, Shurin JB, Smith JE (2007) Global analysis of nitrogen and phosphorus limitation of primary producers in freshwater, marine and terrestrial ecosystems. Ecol Lett 10:1135-1142. doi: 10.1111/j.14610248.2007.01113.x

Gagné JA, Mann KH, Chapman ARO (1982) Seasonal patterns of growth and storage in Laminaria longicruris in relation to differing patterns of availability of nitrogen in the water. Mar Biol 69:91-101. doi: 10.1007/BF00396965

Gevaert F, Davoult D, Creach A, Kling R, Janquin MA, Seuront L, Lemoine Y (2001) Carbon and nitrogen content of Laminaria saccharina in the eastern English Channel: biometrics and seasonal variations. J Mar Biol Assoc UK 81:727-734. doi: $10.1017 / \mathrm{S} 0025315401004532$ 
Golléty C, Crowe T (2013) Contribution of biofilm to ecosystem functioning in rock pools with different macroalgal assemblages. Mar Ecol Prog Ser 482:69-79. doi: $10.3354 /$ meps 10238

Golléty C, Migné A, Davoult D (2008) Benthic metabolism on a sheltered rocky shore: Role of the canopy in the carbon budget. J Phycol 44:1146-1153. doi: 10.1111/j.15298817.2008.00569.x

Golléty C, Riera P, Davoult D (2010) Complexity of the food web structure of the Ascophyllum nodosum zone evidenced by a $\delta 13 \mathrm{C}$ and $\delta 15 \mathrm{~N}$ study. J Sea Res 64:304312. doi: 10.1016/j.seares.2010.04.003

Gomez I, Wiencke C (1998) Seasonal changes in C, N and major organic compounds and their significance to morpho-functional processes in the endemic Antarctic brown alga Ascoseira mirabilis. Polar Biol 19:115-124. doi: 10.1007/s003000050222

Häder D-P, Figueroa FL (1997) Photoecophysiology of marine macroalgae. Photochem Photobiol 66:1-14. doi: 10.1111/j.1751-1097.1997.tb03132.x

Hatcher BG, Chapman ARO, Mann KH (1977) An annual carbon budget for the kelp Laminaria longicruris. Mar Biol 44:85-96. doi: 10.1007/BF00386909

Hubas C, Davoult D, Cariou T, Artigas LF (2006) Factors controlling benthic metabolism during low tide along a granulometric gradient in an intertidal bay (Roscoff Aber Bay, France). Mar Ecol Prog Ser 316:53-68. doi: 10.3354/meps316053

Huppertz K, Hanelt D, Nultsch W (1990) Photoinhibition of photosynthesis in the marine brown alga Fucus serratus as studied in field experiments. Mar Ecol Prog Ser 66:175182. doi: $10.3354 /$ meps066175

Jacob C, Frangoudes K, Mesnildrey L, Lesueur M, Spinec F, Folliard G, Pien S, Rebours C, Meland M, Gallastegi I, Inunziaga Urizarbarrena A, Marques A, Atack T, Dunningham J, Maguire J, Abreu H, Walsh M (2012) Etats des lieux de la filière des macro-algues 
en Europe. Rapport réalisé dans le cadre du projet NETALGAE - Interreg IVB. 12p. (In French)

Jueterbock A, Kollias S, Smolina I, Fernandes JMO, Coyer JA, Olsen JL, Hoarau G (2014) Thermal stress resistance of the brown alga Fucus serratus along the North-Atlantic coast: acclimatization potential to climate change. Mar Genomics 13:27-36. doi: 10.1016/j.margen.2013.12.008

Jueterbock A, Tyberghein L, Verbruggen H, Coyer JA, Olsen JL, Hoarau G (2013) Climate change impact on seaweed meadow distribution in the North Atlantic rocky intertidal. Ecol Evol 3:1356-1373. doi: 10.1002/ece3.541

Kawamitsu Y, Boyer JS (1999) Photosynthesis and carbon storage between tides in a brown alga, Fucus vesiculosus. Mar Biol 133:361-369. doi: 10.1007/s002270050475

Kemp WM, Testa JM (2011) Metabolic balance between ecosystem production and consumption. In: Treatise on estuarine and coastal science. E. Wolanski, D.S. McLusky, pp 83-118

Kersen P, Kotta J, Bučas M, Kolesova N, Dekere Z (2011) Epiphytes and associated fauna on the brown alga Fucus vesiculosus in the Baltic and the North Seas in relation to different abiotic and biotic variables: Epiphytes and associated fauna on brown alga. Mar Ecol 32:87-95. doi: 10.1111/j.1439-0485.2010.00418.x

Knight M, Parke M (1950) A biological study of Fucus vesiculosus L. and F. serratus L. J Mar Biol Assoc U K 29:439-514.

Lehvo A, Bäck S, Kiirikki M (2001) Growth of Fucus vesiculosus L.(Phaeophyta) in the northern Baltic proper: energy and nitrogen storage in seasonal environment. Bot Mar 44:345-350. doi: 10.1515/BOT.2001.044

Maberly SC, Madsen TV (1990) Contribution of air and water to the carbon balance of Fucus spiralis. Mar Ecol Prog Ser 62:175-183. doi: 10.3354/meps062175 
Middelboe AL, Sand-Jensen K, Binzer T (2006) Highly predictable photosynthetic production in natural macroalgal communities from incoming and absorbed light. Oecologia 150:464-476. doi: 10.1007/s00442-006-0526-9

Migné A, Davoult D, Spilmont N, Menu D, Boucher G, Gattuso JP, Rybarczyk H (2002) A closed-chamber $\mathrm{CO}_{2}$-flux method for estimating intertidal primary production and respiration under emersed conditions. Mar Biol 140:865-869. doi: 10.1007/s00227001-0741-1

Migné A, Delebecq G, Davoult D, Spilmont N, Menu D, Gevaert F (2015a) Photosynthetic activity and productivity of intertidal macroalgae: In situ measurements, from thallus to community scale. Aquat Bot 123:6-12. doi: 10.1016/j.aquabot.2015.01.005

Migné A, Golléty C, Davoult D (2015b) Effect of canopy removal on a rocky shore community metabolism and structure. Mar Biol 162:449-457. doi: 10.1007/s00227014-2592-6

Migné A, Spilmont N, Davoult D (2004) In situ measurements of benthic primary production during emersion: seasonal variations and annual production in the Bay of Somme (eastern English Channel, France). Cont Shelf Res 24:1437-1449. doi: 10.1016/j.csr.2004.06.002

Moebus K, Johnson KM, Sieburth JM (1974) Rehydration of desiccated intertidal brown algae: release of dissolved organic carbon and water uptake. Mar Biol 26:127-134. doi: 10.1007/BF00388882

Molina-Montenegro MA, Muoz AA, Badano EI, Morales BW, Fuentes KM, Cavieres LA (2005) Positive associations between macroalgal species in a rocky intertidal zone and their effects on the physiological performance of Ulva lactuca. Mar Ecol Prog Ser 292:173-180. doi: 10.3354/meps292173 
Oswald R, Telford N, Seed R, Happeywood C (1984) The effect of encrusting Bryozoans on the photosynthetic activity of Fucus Serratus L. Estuar Coast Shelf Sci 19:697-702. doi: 10.1016/0272-7714(84)90024-6

Ouisse V, Migné A, Davoult D (2010) Seasonal variations of community production, respiration and biomass of different primary producers in an intertidal Zostera noltii bed (Western English Channel, France). Hydrobiologia 649:3-11. doi:

Paine RT (2002) Trophic control of production in a rocky intertidal community. Science 296:736-739. doi: 10.1126/science.1069811

Pedersen MF, Borum J (1997) Nutrient control of estuarine macroalgae: growth strategy and the balance between nitrogen requirements and uptake. Mar Ecol Prog Ser 161:155-

Quadir A, Harrison PJ, DeWreede RE (1979) The effects of emergence and submergence on the photosynthesis and respiration of marine macrophytes. Phycologia 18:83-88. doi: 10.2216/i0031-8884-18-1-83.1

Raffaelli DG, Hawkins SJ (1999) Intertidal ecology. Kluwer Academic Publishers

Rindi F, Guiry MD (2004) Composition and spatio temporal variability of the epiphytic macroalgal assemblage of Fucus vesiculosus Linnaeus at Clare Island, Mayo, western Ireland. J Exp Mar Biol Ecol 311:233-252. doi: 10.1016/j.jembe.2004.05.009

594 Sand-Jensen K (1977) Effect of epiphytes on eelgrass photosynthesis. Aquat Bot 3:55-63. doi: 10.1016/0304-3770(77)90004-3

596 Staehr PA, Testa JM, Kemp WM, Cole JJ, Sand-Jensen K, Smith SV (2012) The metabolism 597 of aquatic ecosystems: history, applications, and future challenges. Aquat Sci 74:1529. doi: 10.1007/s00027-011-0199-2 
Tait LW, Schiel DR (2010) Primary productivity of intertidal macroalgal assemblages: comparison of laboratory and in situ photorespirometry. Mar Ecol Prog Ser 416:115125. doi: $10.3354 /$ meps 08781

Tait LW, Schiel DR (2011) Dynamics of productivity in naturally structured macroalgal assemblages: importance of canopy structure on light-use efficiency. Mar Ecol Prog Ser 421:97-107. doi: 10.3354/meps08909

Thompson RC, Crowe TP, Hawkins SJ (2002) Rocky intertidal communities: past environmental changes, present status and predictions for the next 25 years. Environ Conserv 29:168-191. doi: 10.1017/S0376892902000115

Underwood AJ (2000) Experimental ecology of rocky intertidal habitats: what are we learning? J Exp Mar Biol Ecol 250:51-76. doi: 10.1016/S0022-0981(00)00179-9

Viana IG, Bode A, Bartholomew M, Valiela I (2015) Experimental assessment of the macroalgae Ascophyllum nodosum and Fucus vesiculosus for monitoring $\mathrm{N}$ sources at different time-scales using stable isotope composition. J Exp Mar Biol Ecol 466:2433. doi: 10.1016/j.jembe.2015.01.014

Wahl M (2009) Marine Hard Bottom Communities: Patterns, Dynamics, Diversity, and Change. Springer Science \& Business Media

Wahl M, Jormalainen V, Eriksson BK, Coyer JA, Molis M, Schubert H, Dethier M, Karez R, Kruse I, Lenz M, Pearson G, Rohde S, Wikström SA, Olsen JL (2011) Stress ecology in Fucus: Abiotic, biotic and genetic interactions. In: Advances in Marine Biology. Elsevier, pp 37-105

Williams SL, Dethier MN (2005) High and dry: Variation in net photosynthesis of the intertidal seaweed Fucus gardneri. Ecology 86:2373-2379. doi: 10.2307/3451026

Young EB, Dring MJ, Savidge G, Birkett DA, Berges JA (2007) Seasonal variations in nitrate reductase activity and internal $\mathrm{N}$ pools in intertidal brown algae are correlated with 
ambient nitrate concentrations. Plant Cell Environ 30:764-774. doi: 10.1111/j.1365-

625 3040.2007.01666.x

626 


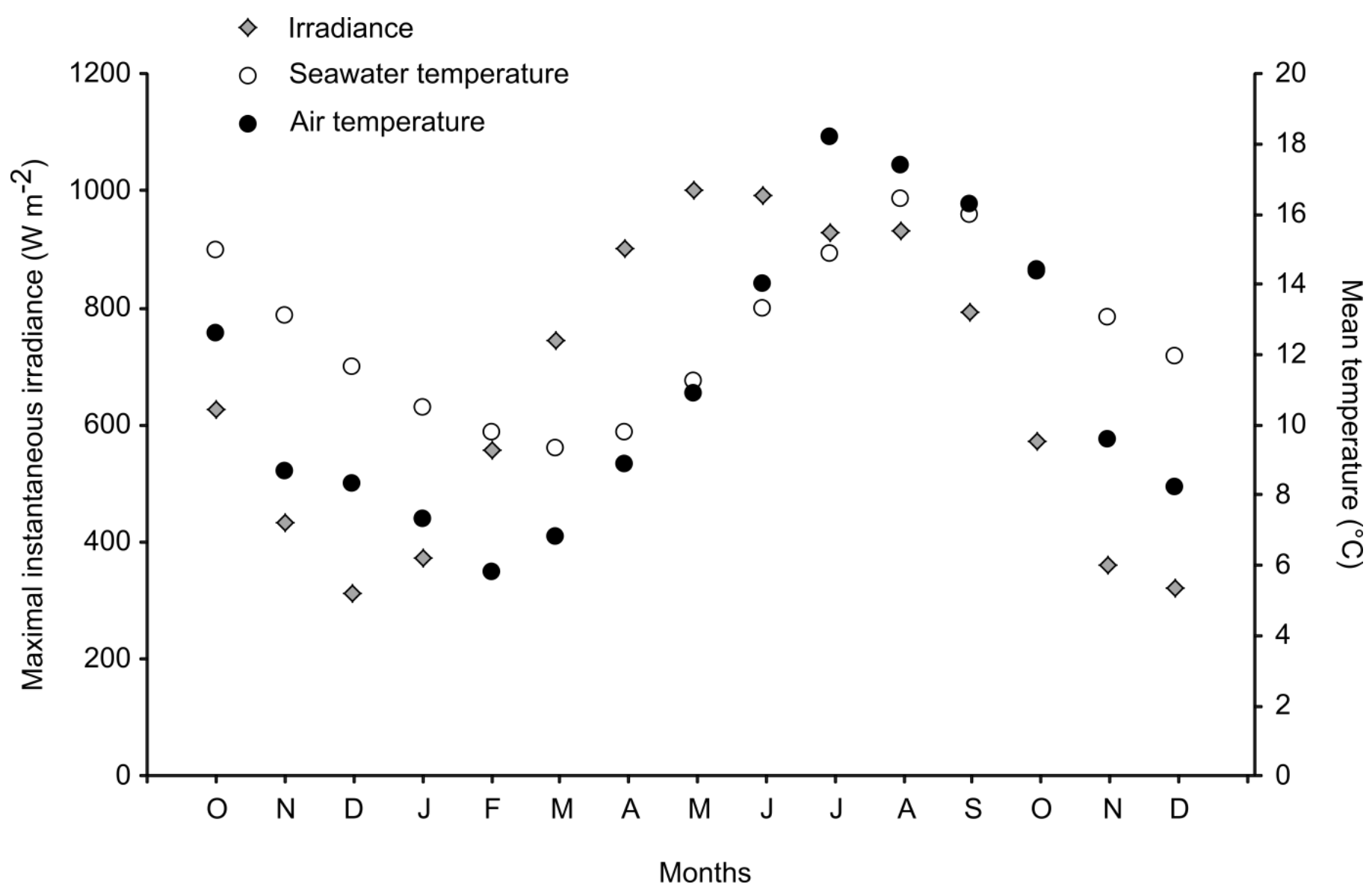

Fig. 1 Monthly maximal instantaneous irradiance, expressed in $\mathrm{W} \mathrm{m}^{-2}$, and monthly mean of seawater and air temperatures, both expressed in ${ }^{\circ} \mathrm{C}$, as a function of time 

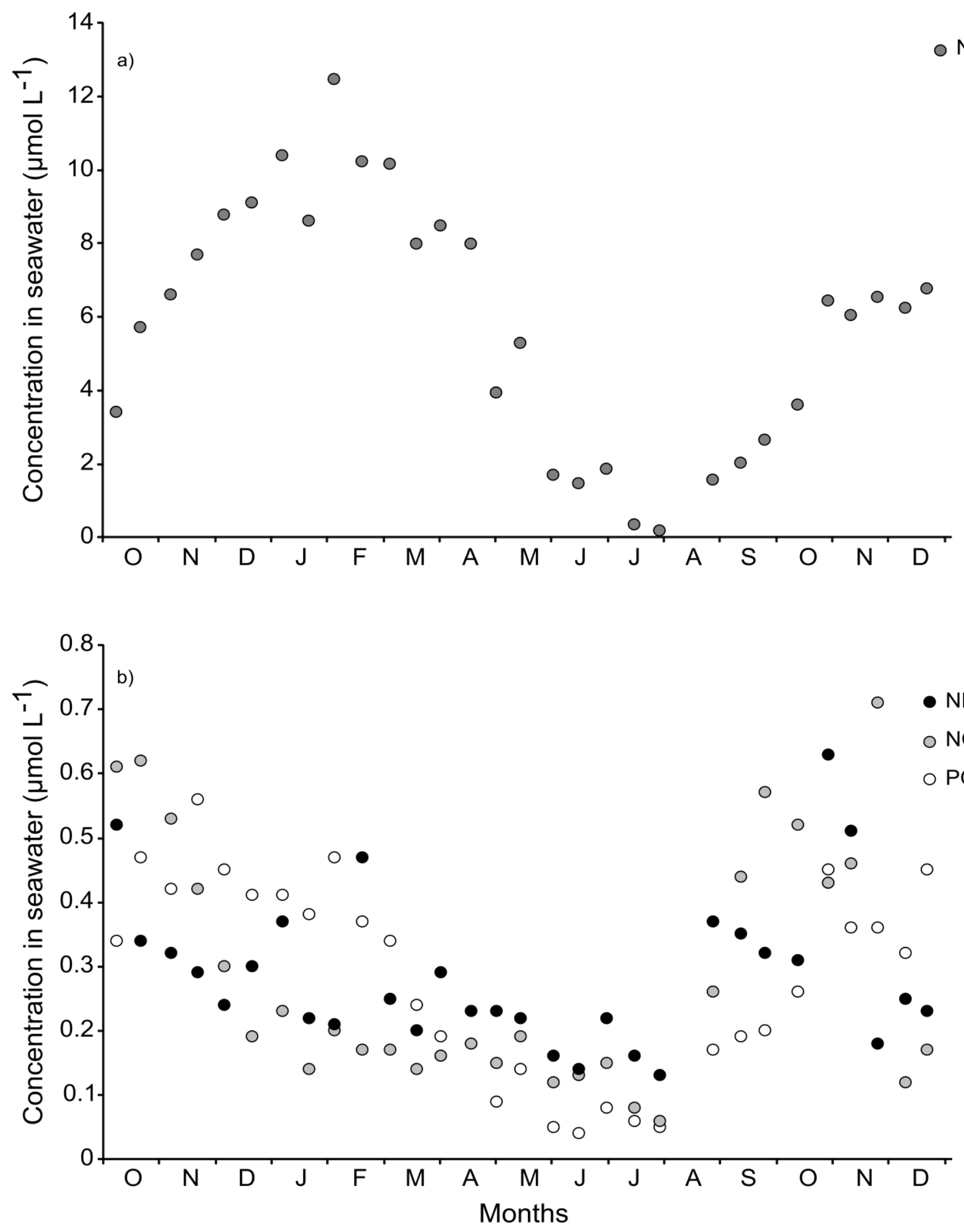

Fig. 2 Seawater concentration of (a) nitrates $\left(\mathrm{NO}_{3}^{-}\right)$and (b) ammonium $\left(\mathrm{NH}_{4}^{+}\right)$, nitrites $\left(\mathrm{NO}_{2}^{-}\right)$ and phosphates $\left(\mathrm{PO}_{4}{ }^{2-}\right)$, expressed in $\mu \mathrm{mol} \mathrm{L}^{-1}$, as a function of time 

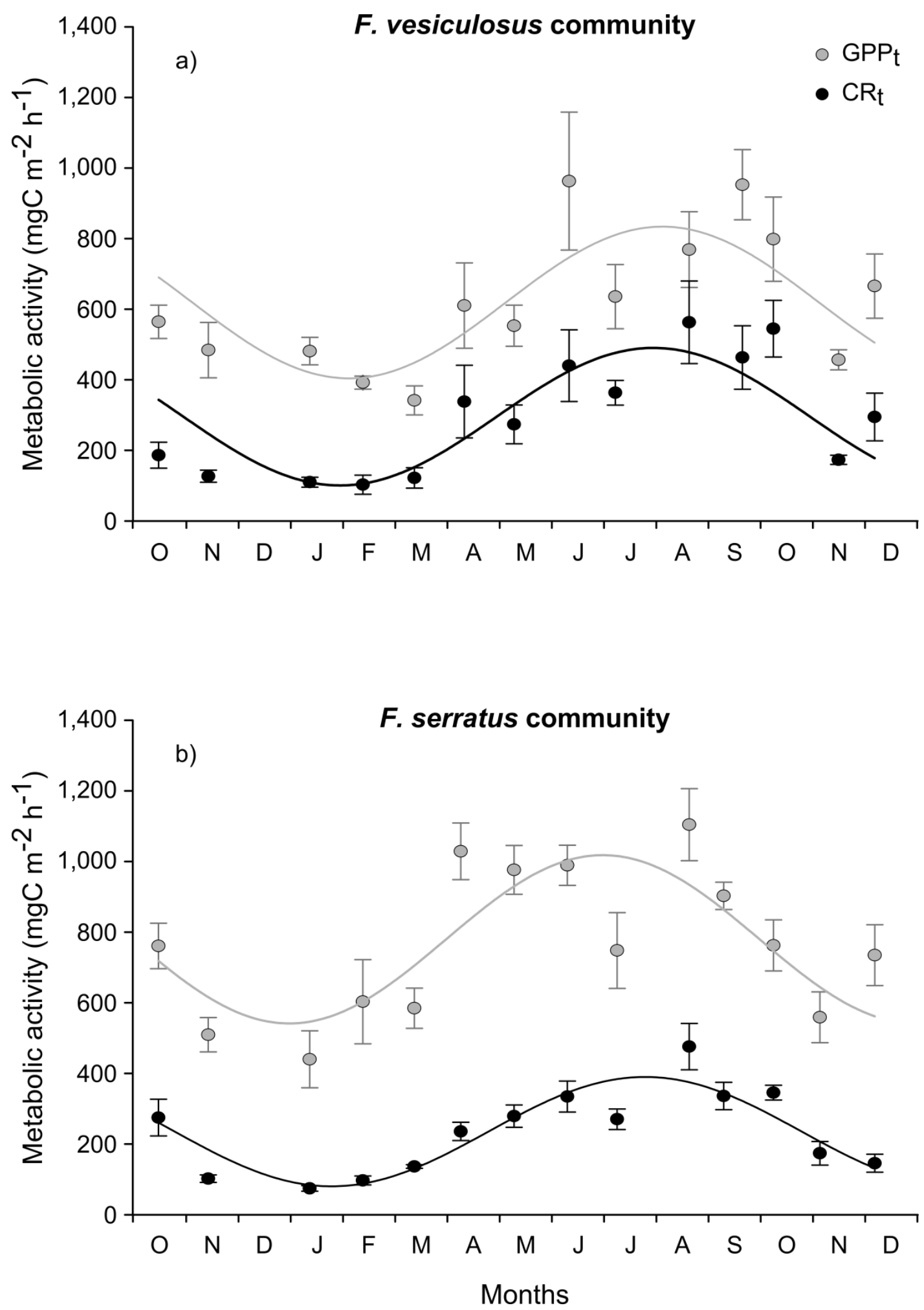

Fig. 3 Mean $( \pm \mathrm{SE})$ community gross primary production $\left(\mathrm{GPP}_{t}\right)$ and respiration $\left(\mathrm{CR}_{t}\right)$, both expressed in $\mathrm{mgC} \mathrm{m}^{-2} \mathrm{~h}^{-1}$, as a function of time, for Fucus vesiculosus (a) and Fucus serratus (b) communities. Grey and dark lines represent the sinusoidal curves fitted on $\mathrm{GPP}_{t}$ and $\mathrm{CR}_{t}$ data sets, respectively 


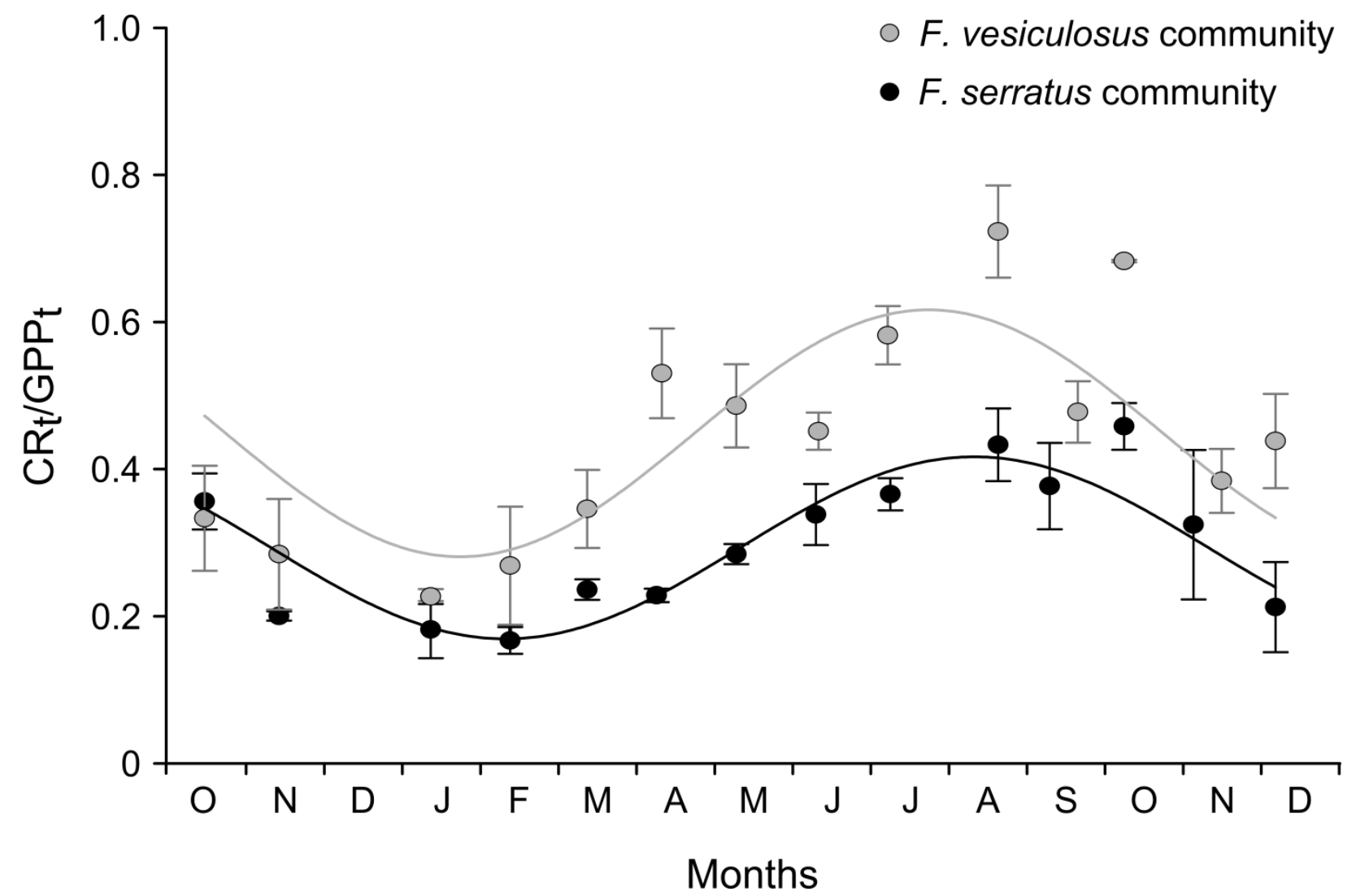

Fig. 4 Mean $( \pm S E)$ metabolic balance, calculated as $\mathrm{CR}_{t} / \mathrm{GPP}_{t}$, as a function of time, for Fucus vesiculosus (grey) and Fucus serratus (dark) communities. Grey and Dark lines represent the sinusoidal curves fitted on $F$. vesiculosus and $F$. serratus communities metabolic balance data sets, respectively 

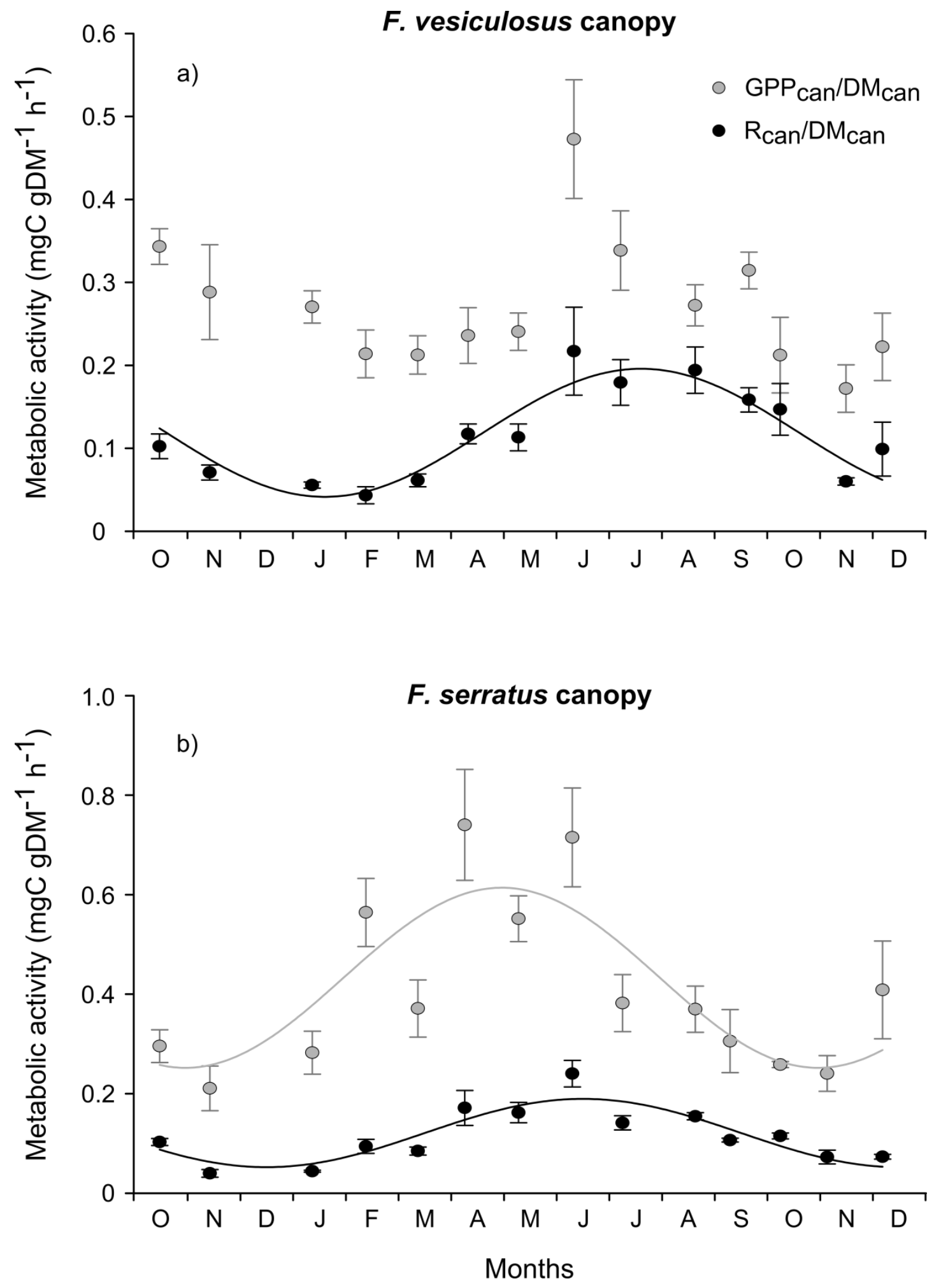

Fig. 5 Mean $( \pm \mathrm{SE})$ gross canopy productivity $\left(\mathrm{GPP}_{\mathrm{can}} / \mathrm{DM}_{\mathrm{can}}\right)$ and canopy respiration rate $\left(\mathrm{R}_{\mathrm{can}} / \mathrm{DM}_{\mathrm{can}}\right)$, both expressed in $\mathrm{mgC} \mathrm{gDM}^{-1} \mathrm{~h}^{-1}$, as a function of time, for Fucus vesiculosus (a) and Fucus serratus (b) canopies. Grey and dark lines represent the sinusoidal curves fitted on productivity and respiration data sets, respectively 

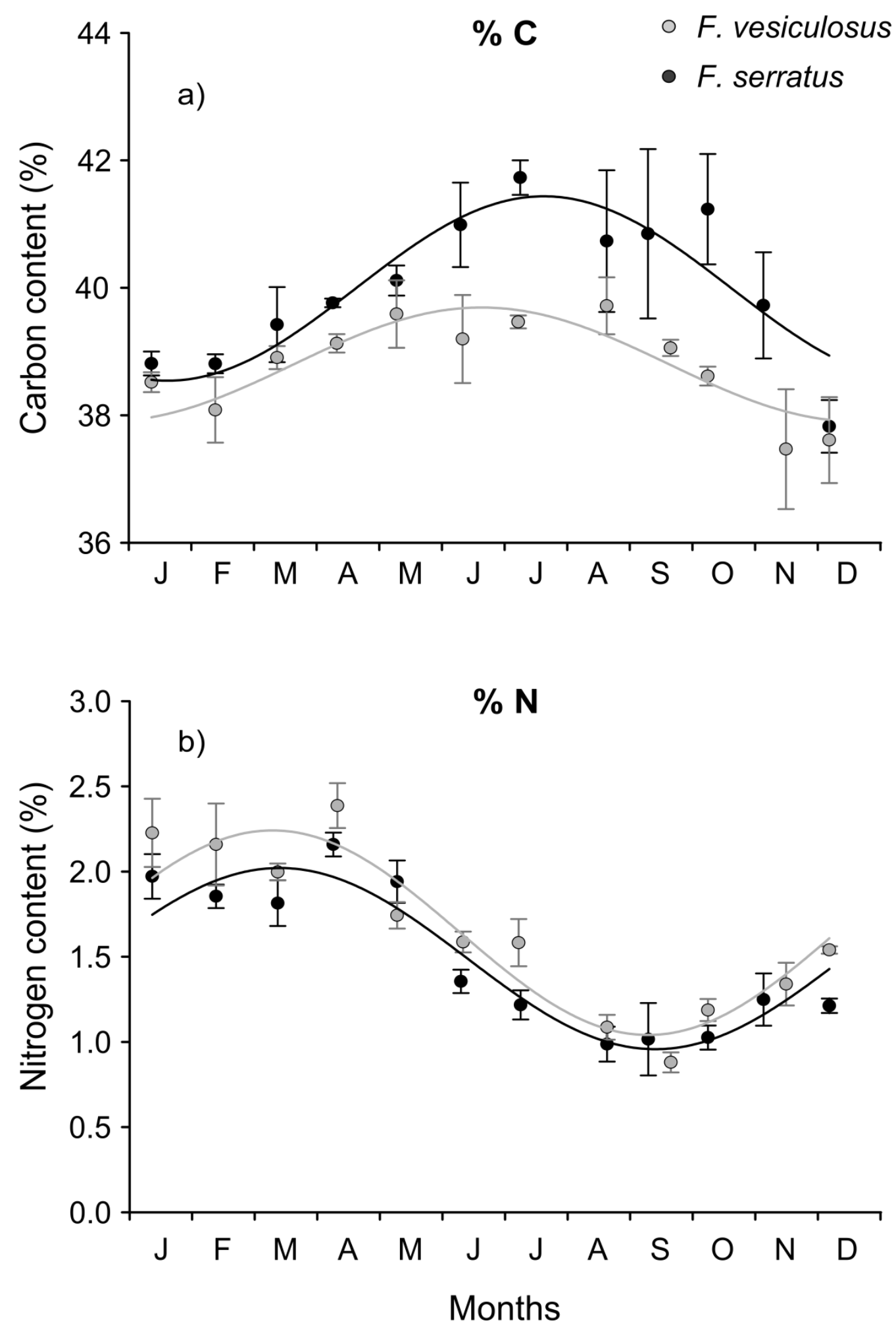

Fig. 6 Mean $( \pm S E) C$ content (a) and $N$ content (b), both expressed in \% of $\mathrm{DM}_{\text {can }}$, as a function of time, for Fucus vesiculosus (grey) and Fucus serratus (dark). Grey and dark lines represent the sinusoidal curves fitted on $F$. vesiculosus and $F$. serratus data sets, respectively 
Table 1: Sinusoidal curve parameters (n, a, b, c and $\mathrm{R}^{2}$ ) and F-test significant level $\left(*: p<0.05 ;{ }^{* *}: p<0.01 ; * * *: p<0.001\right)$ for Fucus vesiculosus and Fucus serratus community gross primary production $\left(\mathrm{GPP}_{t}\right)$, community respiration $\left(\mathrm{CR}_{\mathrm{t}}\right)$, metabolic balance $\left(\mathrm{CR}_{t} / \mathrm{GPP}_{t}\right)$, canopy productivity $\left(\mathrm{GPP}_{\mathrm{can}} / \mathrm{DM}_{\mathrm{can}}\right)$, canopy respiration rate $\left(\mathrm{R}_{\mathrm{can}} / \mathrm{DM}_{\mathrm{can}}\right), \mathrm{C}$ content $(\% \mathrm{C}), \mathrm{N}$ content $(\% \mathrm{~N})$.

\begin{tabular}{|c|c|c|c|c|c|c|c|}
\hline \multicolumn{2}{|c|}{ Community/canopy } & $\mathbf{n}$ & a & b & c & $\mathbf{R}^{2}$ & $p$ \\
\hline \multirow{2}{*}{$\mathrm{CR}_{\mathrm{t}}$} & F. vesiculosus & 14 & 295.6 & -194.8 & 7.4 & 0.634 & ** \\
\hline & F. serratus & 14 & 235.2 & 154.8 & 4.3 & 0.787 & $* * *$ \\
\hline \multirow{2}{*}{$\mathrm{GPP}_{\mathrm{t}}$} & F. vesiculosus & 14 & 618.9 & -214.9 & 7.3 & 0.555 & * \\
\hline & F. serratus & 14 & 779.7 & 238.2 & 17.3 & 0.604 & * \\
\hline \multirow{2}{*}{$\mathrm{CR}_{\mathrm{t}} / \mathrm{GPP}_{\mathrm{t}}$} & F. vesiculosus & 14 & 0.4487 & 0.1678 & 4.3259 & 0.556 & $*$ \\
\hline & F. serratus & 14 & 0.2930 & 0.1238 & 4.0211 & 0.804 & $* * *$ \\
\hline \multirow{2}{*}{$R_{\text {can }} / \mathrm{DM}_{\text {can }}$} & F. vesiculosus & 14 & 0.1187 & -0.0772 & 1.2554 & 0.851 & $* * *$ \\
\hline & F. serratus & 14 & 0.1210 & -0.0686 & 1.8345 & 0.779 & $* * *$ \\
\hline $\mathrm{GPP}_{\mathrm{can}} / \mathrm{DM}_{\mathrm{can}}$ & F. serratus & 14 & 0.4330 & 0.1810 & -0.5001 & 0.668 & $* *$ \\
\hline \multirow{2}{*}{$\% \mathrm{C}$} & F. vesiculosus & 12 & 38.80 & 0.89 & 4.91 & 0.766 & ** \\
\hline & F. serratus & 12 & 39.99 & 1.45 & 4.39 & 0.807 & $* *$ \\
\hline \multirow{2}{*}{$\% \mathbf{N}$} & F. vesiculosus & 12 & 1.64 & -0.60 & 3.52 & 0.873 & *** \\
\hline & F. serratus & 12 & 1.49 & -0.53 & 3.46 & 0.878 & $* * *$ \\
\hline
\end{tabular}


Table 2: Wilcoxon signed rank test results $(\mathrm{V}, p)$ for differences between Fucus vesiculosus and Fucus serratus in mean community gross primary production $\left(\mathrm{GPP}_{t}\right)$, community respiration $\left(\mathrm{CR}_{t}\right)$, metabolic balance $\left(\mathrm{CR}_{t} / \mathrm{GPP}_{t}\right)$, canopy productivity $\left(\mathrm{GPP}_{\mathrm{can}} / \mathrm{DM}_{\mathrm{can}}\right)$, canopy respiration rate $\left(\mathrm{R}_{\mathrm{can}} / \mathrm{DM}_{\mathrm{can}}\right), \mathrm{C}$ content $(\% \mathrm{C}), \mathrm{N}$ content $(\% \mathrm{~N})$.

\begin{tabular}{ccc} 
& $\mathbf{V}$ & $\boldsymbol{p}$ \\
\cline { 2 - 3 } $\mathbf{C R}_{\mathbf{t}}$ & 15 & $\mathbf{0 . 0 1 7}$ \\
$\mathbf{G P P}_{\mathbf{t}}$ & 12 & $\mathbf{0 . 0 0 9}$ \\
$\mathbf{C R}_{\mathbf{t}} / \mathbf{G P P}_{\mathbf{t}}$ & 3 & $<\mathbf{0 . 0 0 1}$ \\
$\mathbf{R}_{\text {can }} / \mathrm{DM}_{\mathrm{can}}$ & 50 & 0.903 \\
$\mathbf{G P P}_{\text {can }} / \mathrm{DM}_{\text {can }}$ & 13 & $\mathbf{0 . 0 1 1}$ \\
$\% \mathbf{C}$ & 78 & $<\mathbf{0 . 0 0 1}$ \\
$\% \mathbf{N}$ & 9 & $\mathbf{0 . 0 1 6}$
\end{tabular}


Table 3: Results of linear multiple regressions $\left(\mathrm{R}^{2}, p\right)$ analyzing relationships between $\mathrm{GPP}_{\mathrm{t}}$ or $\mathrm{CR}_{\mathrm{t}}$ and environmental variables, for both community. Max $_{\text {irr }}=$ monthly maximal instantaneous irradiance; $\mathrm{T}_{\text {air }}=$ monthly mean air temperature; $\mathrm{T}_{\text {seawater }}=$ monthly mean seawater temperature; $\mathrm{NO}_{3}{ }^{-}=$monthly mean nitrates concentration in seawater; $\mathrm{NO}_{2}{ }^{-}=$monthly mean nitrites concentration in seawater; $\mathrm{NH}_{4}{ }^{+}=$monthly mean ammonium concentration in seawater; $\mathrm{PO}_{4}{ }^{2-}=$ monthly mean phosphates concentration in seawater; $\mathrm{DM}_{\text {can }}=$ canopy dry mass.

\begin{tabular}{|c|c|c|c|c|}
\hline & Community & Environmental variables & $\mathbf{R}^{2}$ & $p$ \\
\hline \multirow{2}{*}{$\mathrm{GPP}_{\mathrm{t}}$} & F. vesiculosus & $\mathrm{NO}_{3}^{-}, \mathrm{DM}_{\text {can }}$ & 0.684 & 0.002 \\
\hline & F. serratus & $\mathrm{Max}_{\text {irr }}, \mathrm{T}_{\text {air }}, \mathrm{NO}_{3}^{-}, \mathrm{NO}_{2}^{-}, \mathrm{NH}_{4}^{+}, \mathrm{PO}_{4}^{2-}$ & 0.840 & 0.016 \\
\hline \multirow{2}{*}{$\mathrm{CR}_{\mathrm{t}}$} & F. vesiculosus & $\mathrm{T}_{\text {air }}, \mathrm{T}_{\text {seawater }}, \mathrm{DM}_{\mathrm{can}}$ & 0.898 & $<0.001$ \\
\hline & F. serratus & $\mathrm{T}_{\mathrm{air}}$ & 0.749 & $<0.001$ \\
\hline
\end{tabular}

